\title{
FILM DOKUMENTER \\ PTI : RUMAHKU (SEBUAH CATATAN, SEBUAH KISAH)
}

\author{
I Gusti Ngurah Agung Pramasurya Dwi Septian"1), Gede Saindra Santyadiputra"2), I Made Agus \\ Wirawan ${ }^{3)}$. \\ ${ }^{1}$ Fakultas Teknik dan Kejuruan, Universitas Pendidikan Ganesha (penulis 1) \\ email: agungpramasurya87@gmail.com \\ ${ }^{2}$ Fakultas Teknik dan Kejuruan, Universitas Pendidikan Ganesha (penulis 2) \\ email: gsaindras@undiksha.ac.id \\ ${ }^{3}$ Fakultas Teknik dan Kejuruan, Universitas Pendidikan Ganesha (penulis 3) \\ email: agus.wirawan@undiksha.ac.id
}

\begin{abstract}
Abstrak
Penelitian ini bertujuan: (1) Untuk menghasilkan rancangan dan mengimplementasikan film dokumenter PTI : Rumahku (Sebuah Catatan, Sebuah Kisah), (2) Untuk mengetahui respon dari mahasiswa PTI mengenai film dokumenter PTI : Rumahku (Sebuah Catatan, Sebuah Kisah).

Metode penelitian yang digunakan pada film dokumenter PTI : Rumahku (Sebuah Catatan, Sebuah Kisah) adalah Research and Development dengan model cyclic strategy. Yang menjadi subjek penelitian adalah sejarah dan perkembangan jurusan Pendidikan Teknik Informatika Undiksha Singaraja.

Hasil yang diperoleh dari uji ahli isi adalah isi dari film dokumenter PTI : Rumahku (Sebuah Catatan, Sebuah Kisah) adalah sudah sesuai dengan sejarah dan perkembangan dari jurusan Pendidikan Teknik Informatika. Kemudian untuk uji ahli media diperoleh hasil bahwa film dokumenter PTI : Rumahku (Sebuah Catatan, Sebuah Kisah) sudah sesuai dengan kaidah sinematografi. Sedangkan dari uji respon penonton disebar ke 40 responden. Berdasarkan data uji responden yang telah dilakukan, didapatkan hasil rata-rata presentase yaitu $91,6 \%$ dengan tingkat pencapaian sangat baik. Kesimpulan yang didapatkan yaitu film dokumenter PTI : Rumahku (Sebuah Catatan, Sebuah Kisah) sudah sangat baik dan bisa digunakan sebagai media pemberi inspirasi dan promosi jurusan.
\end{abstract}

Kata kunci: Film Dokumenter, Pendidikan Teknik Informatika, promosi, inspirasi, cyclic strategy.

\begin{abstract}
This research aimed at: (1) Produce the design and implement documentary film PTI: Rumahku (Sebuah Catatan, Sebuah Kisah), (2) Know the response from PTI students about documentary film PTI: Rumahku (Sebuah Catatan, Sebuah Kisah).

The research method used that was in the documentary film PTI: Rumahku (Sebuah Catatan, Sebuah Kisah) was Research and Development with cyclic strategy model. The subject of research was the history and development of Informatics Engineering Department of Undiksha Singaraja.

The results obtained from the expert test content is the content of the documentary film PTI: Rumahku (Sebuah Catatan, Sebuah Kisah) is in accordance with the history and development of the Department of Information Engineering Education. Then for the expert test media obtained the result that the documentary film PTI: Rumahku (Sebuah Catatan, Sebuah Kisah) is in accordance with the rules of cinematography. The result was the test audience response spread to 40 respondents. Based on the test data of responden it was found that the percentage was $91,6 \%$, which was categorized was as a very good achievement level. The conclusion was the documentary film PTI: Rumahku (Sebuah Catatan, Sebuah Kisah) was very good and can be used as a media of inspiration and promotion of the department.
\end{abstract}

Keywords : Documentary Film, Informatics Engineering Education, promotion, inspiration, cyclic strategy. 


\section{PENDAHULUAN}

Pendidikan Teknik Informatika (PTI) merupakan salah satu jurusan di Universitas Pendidikan Ganesha (Undiksha). Jurusan PTI yang berdiri pada tanggal 9 September 2007, memiliki dedikasi yang sangat besar untuk menghasilkan alumni yang bermanfaat baik untuk masyarakat, negara, dan dunia. Pendidikan Teknik Informatika merupakan salah satu jurusan yang bergerak dalam bidang teknologi dan Informasi. Dengan berbagai kemajuan teknologi di dunia, jurusan PTI memiliki visi misi yang bertujuan menghasilkan tenaga pengajar yang produktif dan mampu bersaing dalam dunia informatika. Jurusan PTI bernaung di Fakultas Teknik dan Kejuruan (FTK) UNDIKSHA. Banyak prestasi berhasil diraih oleh PTI. Salah satunya adalah selalu menjadi langganan untuk mengikuti lomba Gema Nasional Informatika (GEMASTIK). Himpunan Mahasiswa Jurusan (HMJ) PTI memiliki banyak prestasi yang tidak bisa dianggap remeh. Contohnya adalah berturut - turut menjadi juara umum Pagelaran Akhir Tahun (PAT) yang diadakan oleh Senat Mahasiswa FTK (SMFTK).

Untuk memperingati ulang tahun jurusan, PTI memiliki kegiatan yang disebut dengan Information of Technology Today (IT2D). Kegiatan IT2D ini merupakan kegiatan yang bertujuan untuk memperkenalkan teknologi - teknologi terbaru. Selain IT2D, terdapat juga Seminar Nasional Pendidikan Teknik Informatika (SENAPATI)..

Banyak hasil kreativitas yang berhasil dibuat oleh mahasiswa dan dosen PTI. Salah satunya adalah logo jurusan. Pembuatan logo tidak bisa sembarangan karena logo melambangkan arti dari sebuah instansi. Logo PTI merupakan hasil kreativitas dari salah satu dosen PTI, yaitu I Made Gede Sunarya, S.Kom,.M.Sc. Berdasarkan hasil wawancara yang dilakukan peneliti dengan Bapak I Made Gede Sunarya, S.Kom,.M.Sc pada tanggal 18 Januari 2016, logo jurusan tersebut menggambarkan bahwa antara dosen dengan mahasiswa PTI terdapat ikatan dan saling bekerjasama.
Tidak hanya sebatas logo, jurusan PTI juga menghasilkan animator animator handal. Salah satu karya yang dihasilkan adalah Tude. Tude merupakan salah satu karakter/maskot di jurusan PTI. Tude dibuat oleh I Ketut Wiryadana.

Untuk mempromosikan jurusan, Kadek Dwiyoga Adi Palguna bersama bandnya, Teh Tawar, yang semua personilnya adalah mahasiswa mahasiswa PTI membuat jingle PTI sekaligus video profil jurusan.

Ketiga hasil karya dosen dan mahasiswa tersebut dan banyaknya prestasi yang berhasil diraih oleh PTI menandakan bahwa jurusan PTI adalah jurusan yang berkualitas serta berbeda dengan jurusan - jurusan yang lain. Terdapat proses yang tidak pernah terekspos sehingga bisa menghasilkan karya dan prestasi bagi PTI. Proses tersebut sebaiknya dimunculkan agar mahasiswa PTI mengetahui sejarah dan sepak terjang jurusannya sendiri sehingga bisa dijadikan inspirasi untuk menghasilkan karya - karya dan prestasi yang lebih baik.

Sejarah dan perkembangan jurusan PTI seharusnya diketahui oleh semua civitas akademika jurusan PTI, khususnya di kalangan mahasiswa. Namun kenyataannya, banyak mahasiswa jurusan PTI tidak mengetahui bagaimana sejarah berdirinya jurusan. Pernyataan tersebut diperkuat dengan hasil penyebaran angket, dimana dari 20 sampel yang disebar ke mahasiswa jurusan PTI, sebanyak $90 \%$ responden tidak mengetahui sejarah berdirinya jurusan PTI. Oleh karena itu, diperlukan suatu media yang tepat untuk menceritakan sejarah perkembangan jurusan PTI Undiksha Singaraja sekaligus menjadi media promosi jurusan.

Salah satu manfaat mempelajari sejarah adalah memberikan inspiratif (Ana, 2015). Dengan diceritakannya sejarah dan perkembangan jurusan PTI, diharapkan semua civitas akademika mengetahui sejarah berdirinya jurusan serta terinspirasi untuk menghasilkan prestasi - prestasi untuk jurusan sehingga pamor jurusan meningkat. 
Solusi yang ditawarkan adalah menggunakan media audio visual. Audio visual adalah media instruksional modern yang sesuai dengan perkembangan zaman (kemajuan ilmu pengetahuan dan teknologi), meliputi media yang dapat dilihat dan didengar. Bentuk aplikasinya dari komunikasi visual itu bisa berbentuk film. Dengan kata lain film bisa digunakan diberbagai macam alat dan sangat mudah memperluaskannya, karena itulah film bisa dijadikan media yang tepat untuk memudahkan penonton mengenal dan mengetahui tentang kebudayaan yang ada (Masnuna, 2012). Film yang paling sering ditemui dengan mengenalkan sejarah budaya dan tradisi adalah film dokumenter (Cheng \& Barker, 2011).

Jurusan PTI juga memiliki video company/profil. Fungsi video company/profil jurusan PTI adalah untuk mempromosikan jurusan PTI sehingga bisa dikenal luas oleh masyarakat. Materi di dalam video company/profil tersebut juga menampilkan sekilas mengenai jurusan PTI. Berbeda dengan film dokumenter yang akan dibuat oleh peneliti. Tujuan utama pembuatan film dokumenter ini adalah untuk bisa memberikan inspirasi bagi mahasiswa mahasiswa PTI sesuai dengan materi dalam film yang akan menceritakan sejarah berdirinya jurusan serta prestasi prestasi yang berhasil diraih oleh jurusan PTI. Selain itu, dengan diceritakan prestasi - prestasi yang diraih oleh jurusan PTI, film ini dapat juga digunakan sebagai salah satu media promosi bagi jurusan PTI untuk menarik minat lulusan siswa SMA/SMK berkuliah di jurusan PTI.

\section{PENDIDIKAN TEKNIK INFORMATIKA}

\begin{tabular}{lccc}
\multicolumn{2}{c}{ Pendidikan Teknik } & \multicolumn{2}{c}{ Informatika } \\
merupakan salah satu jurusan di & juran \\
Universitas & Pendidikan & Ganesha \\
(UNDIKSHA), & Singaraja & Bali. & PTI
\end{tabular} merupakan salah satu jurusan yang bergerak dalam bidang teknologi dan Informasi. PTI resmi menjadi sebuah jurusan di Undiksha pada tahun 2007, dengan tanggal peringatan hari jadi setiap tanggal 9 September 2007.

\section{LOGO PENDIDIKAN TEKNIK INFORMATIKA}

Pendidikan Teknik Informatika, yang berdiri pada tahun 2007 memiliki logo jurusan. Logo tersebut dibuat oleh Bapak I Made Gede Sunarya, S.Kom,.M.Cs. Logo jurusan ini diadopsi oleh Himpunan Mahasiswa Jurusan (HMJ) PTI sebagai lambang organisasi. Berikut merupakan makna dari logo jurusan Pendidikan Teknik Informatika seperti pada Gambar 1.

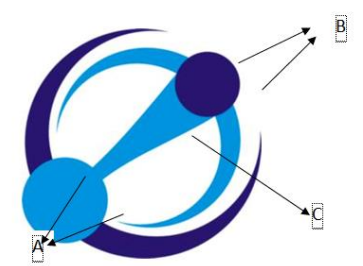

Gambar 1 Logo Jurusan Pendidikan Teknik Informatika

Arti Logo

a) Komponen $\mathrm{A}$ melambangkan dosen yang merangkul dan membimbing mahasiswa

b) Komponen $\mathrm{B}$ melambangkan mahasiswa yang berada dalam rangkulan dan bimbingan dosen

c) Komponen $\mathrm{C}$ melambangkan koordinasi dan hubungan yang harmonis antara dosen dengan mahasiswa

Perbedaan warna antara bulatan (kepala) dan bentuk lengkung (tangan) baik pada komponen 1 (dosen) maupun komponen 2 (mahasiswa) mencerminkan penegasan bahwa antara dosen dan mahasiswa senantiasa saling bertukar pikiran

\section{TUDE}

Sebagai salah satu jurusan di Undiksha, Pendidikan Teknik Informatika memiliki memiliki maskot jurusan yang bernama Tude. Tude diciptakan oleh mantan mahasiswa PTI yang bernama I Ketut Wiryadana. Karakter Tude ini melambangkan mahasiswa jurusan PTI. Karakter Tude yang dimaksud adalah seperti pada Gambar 2. 


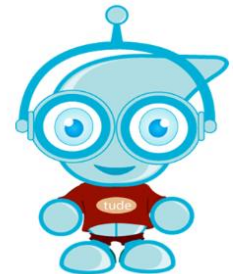

Gambar 2 Maskot Jurusan PTI, Tude

\section{JINGLE PTI}

Pendidikan Teknik Informatika juga memiliki jingle jurusan. Jingle ini diciptakan oleh mahasiswa PTI bernama Kadek Dwiyoga Adi Palguna. Gambar 3 adalah lirik lagu dari Jingle PTI.

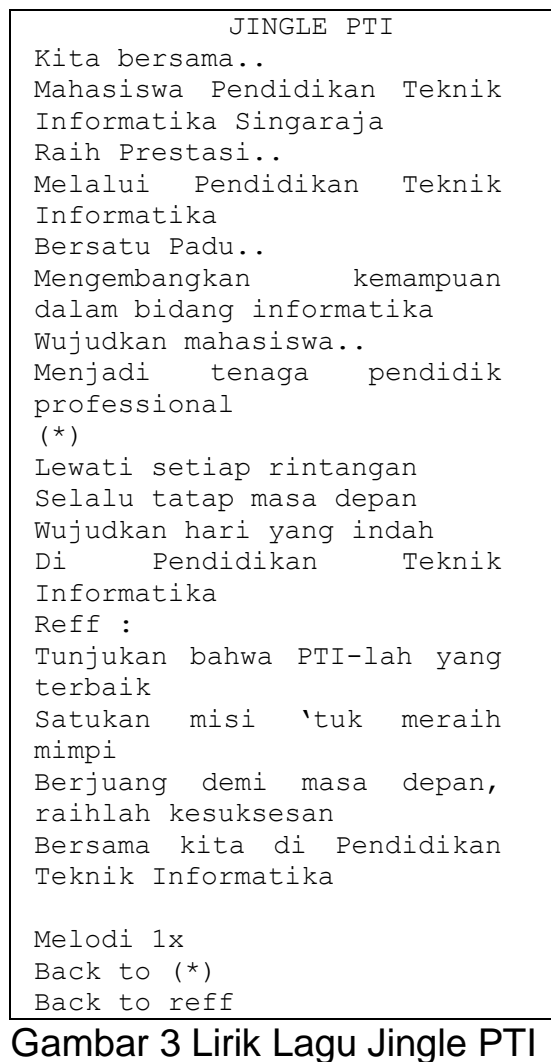

\section{FILM DOKUMENTER}

Film adalah karya cipta seni dan budaya yang dibuat berdasarkan asas sinematografi dengan direkam pada peta seluloid, pita video, piringan video, dan/atau bahan atau hasil penemuan teknologi lainnya dalam segala bentuk, jenis dan ukuran melalui proses kimiawi, proses elektronik, atau proses lainnya, dengan atau tanpa suara, yang dapat dipertunjukkan dan/atau ditayangkan dengan system proyeksi mekanik, elektronik, dan/atau penayangan film
(Effendy, 2011). Dokumenter adalah dokumentasi dalam bentuk film mengenai suatu peristiwa bersejarah atau suatu aspek seni budaya yang mempunyai makna khusus agar dapat menjadi alat penerangan dan alat pendidikan (Kebudayaan, 2016). Jadi film dokumenter adalah karya cipta seni dan budaya yang dibuat berdasarkan asas sinematografi dengan direkam pada peta seluloid, pita video, piringan video, dan/atau bahan atau hasil penemuan teknologi lainnya dalam segala bentuk, jenis dan ukuran, yang dapat dipertunjukkan dan/atau ditayangkan dengan system proyeksi mekanik, elektronik, dan/atau penayangan film dimana film tersebut menceritakan suatu peristiwa bersejarah atau suatu aspek seni budaya yang mempunyai makna khusus agar dapat menjadi alat penerangan dan alat pendidikan.

Film dokumenter mempunyai 2 (dua) syarat yang harus dipenuhi, yaitu: tidak ada usaha untuk menipu penonton dan peristiwanya tidak bertentangan dengan rekonstruksinya. Strategi yang efektif untuk membuat film dokumenter yang menarik dan tepat sasaran adalah mencari masalah-masalah aktual yang sedang hangat di masyarakat, sehingga audience penasaran untuk menemukan jawabannya dalam film dokumenter tersebut (Prihantono, Natadja, \& Setiawan, 2009).

Film dokumenter dibagi menjadi delapan jenis. Jenis-jenis film dokumeter, antara lain

1. Laporan Perjalanan

2. Sejarah

3. Biografi :
a) Potret
b) Biografi
c) Profil

4. Nostalgia

5. Rekonstruksi

6. Investigasi

7. Perbandingan dan Kontradiksi

8. Ilmu Pengetahuan

9. Buku Harian

10. Association Picture Story

11. Dokudrama (School, 2014).

Pembuatan film dokumenter dibagi menjadi empat tahapan, antara lain:

1. Script Development

2. Pra Produksi 
3. Produksi

4. Pasca Produksi (Suardika, 2017).

\section{METODE}

Metode cyclic strategy atau strategi berputar merupakan sebuah metode yang ada kalanya suatu tahap perlu diulang kembali sebelum tahap berikutnya dilanjutkan. Pengulangan tahap ini sering disebut dengan loop. Pengulangan tahap ini dimaksudkan untuk menampung umpan balik (feed back) sebelum tahap berikutnya dilanjutkan (Sarwono, 2007). Tahap - tahap yang ada pada metode cyclic strategy dapat dilihat pada Gambar 4.

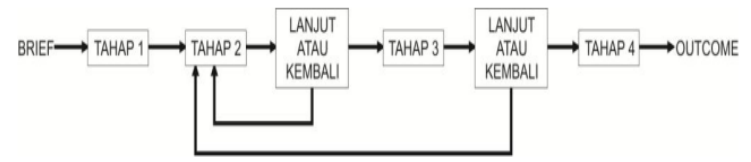

Gambar 4. Tahapan Metode Cyclic Strategy

\section{A. Brief}

Brief merupakan tahap awal dari perancangan Film Dokumenter PTI : Rumahku (Sebuah Catatan, Sebuah Kisah) . Pada tahapan ini dibagi menjadi beberapa fase, yaitu :

1) Pemantapan Ide

2) Penawaran ide

3) Riset Awal

B. Tahap 1

Tahap 1 ini dibagi menjadi beberapa fase, antara lain:

1) Pengumpulan Data

Teknik pengumpulan data tersebut dijabarkan sebagai berikut.:
a. Observasi.
b. Wawancara.
c. Angket
d. Studi Pustaka.

C. Analisis

Rincian dari fase analisis kebutuhan, sebagai berikut.
a. Analisa Talent
b. Analisa Lokasi
c. Analisa Alat
d. Analisa Crew
e. Analisa SWOT
f. Analisa STP.

D. Tahap 2

Pada tahap 2 berisi metode perancangan film bagian pra produksi. Pra produksi merupakan tahapan persiapan atau perencanaan dalam pembuatan sebuah film. Tahapan ini berguna untuk mengurangi kesalahan dan meminimalisir kurang koordinasinya komunikasi antar personil yang bertugas agar mampu melaksanakan tugasnya masing-masing. Informasi yang telah terkumpul pada fase pengumpulan data akan dipakai acauan dan bahan dalam fase pra produksi. Pra produksi meliputi beberapa tahapan, yaitu perancangan ide cerita, sinopsis, skenario, storyline dan storyboard.

\section{E. Evaluasi 1}

Setelah tahap 2 ini akan ada pengujian yang bertujuan untuk mengecek kembali apakah semua bagian dalam tahap 1 dan tahap 2 telah terlaksana. Jika ada yang belum terlaksana maka akan dilakukan looping/pengulangan dengan merevisi kembali rancangan film. Sedangkan jika semua telah terlaksana maka akan dilajutkan ke tahap berikutnya. Pengujian disini dilakukan oleh peneliti itu sendiri.

F. Tahap 3 Adapun fase-fase yang terdapat pada Tahap 3 yaitu :

1) Produksi Pada fase ini dibagi menjadi dua, antara lain:
a. Video Production
b. Audio Production

2) Pasca Produksi

Dalam tahapan pasca produksi dilakukan beberapa hal, antara lain:
a. Video Editing
b. Sound Editing
c. Rendering
d. Review Editing

\section{G. Evaluasi 2}

Setelah Tahap 3 selesai, maka film dokumenter tersebut dievaluasi oleh para ahli di Tahap Evaluasi 2. Terdapat da pengujian, yaitu uji ahli isi dan uji ahli media 


\section{H. Tahap 4}

Tahap 4 merupakan tahapan akhir sebelum film ini disebarluaskan. Pada tahap 4 ini terdapat fase mastering. Mastering merupakan proses dimana file yang telah di-render dipindahkan kedalam media DVD atau media lainya. Pada tahap ini juga dilakukan perancangan desain cover.

\section{Outcome}

Outcome merupakan tahapan terakhir dari pembuatan film dokumenter ini. Tahap terakhir yaitu publikasi. Produk akhir film yang telah dikemas dalam bentuk DVD siap dipublikasikan, target publikasi disesuaikan dengan target penonton. Pada tahap ini juga dilakukan promosi yaitu dengan cara membuat poster dan trailer film. Tahap ini juga dilakukan uji respon dengan tujuan untuk mengetahui respon penonton tentang film dokumenter.

\section{HASIL DAN PEMBAHASAN HASIL}

A. Brief

1) Pemantapan ide

Setelah mendapatkan ide/topik untuk film dokumenter, maka ide/topic tersebut dimantapkan dengan cara membaca buku, artikel serta menonton film - film dokumenter sehingga memperoleh teori - teori yang mendukung penelitian.

2) Penawaran ide

Penawaran ide penelitian ke pihak jurusan Pendidikan Teknik Informatika dilakukan dan disetujui pada tanggal 11 Desember 2015.

3) Riset awal

Setelah ide/topik diterima, langkah selanjutnya adalah mencari informasi mengenai ide/topik yang telah dirancang.

\section{B. Tahap 1}

Pada fase pengumpulan data menggunakan teknik observasi, didapatkan hasil dimana yang dijadikan sebagai subjek penelitian adalah seluruh civitas akademika jurusan Pendidikan Teknik Informatika Undiksha Singaraja.
Pada fase pengumpulan data juga dilakukan menggunakan teknik wawancara dengan tokoh - tokoh yang mengetahui seluk beluk jurusan Pendidikan Teknik Informatika Undiksha Singaraja. Untuk mengetahui seberapa tahunya mahasiswa - mahasiswa jurusan PTI mengenai jurusannya sendiri, maka disebarkan angket kuisioner sejumlah 20 angket, dimana hasil angket tersebut menunjukan bahwa $90 \%$ mahasiswa PTI tidak mengetahui sejarah jurusan PTI.

Dari hasil pengumpulan data tersebut, maka didapatkan hasil sebagai berikut :
a) Penentuan talent
(1) Narasumber
(2) Pemeran.
b) Penentuan lokasi
c) Penentuan Alat
d) Penentuan Crew
e) Penentuan SWOT
f) Penentuan STP
C. Tahap 2

Pada tahap ini terdapat fase pra produksi. Dalam tahap ini, Konsep direalisasikan dalam bentuk sinopsis sebelum dituangkan ke dalam bentuk ide/konsep film, storyline, scenario, dan storyboard. Adapun hasil didapatkan pada tahapan ini antara lain:
a) Ide Cerita
b) Sinopsis
c) Storyline
d) Skenario
e) Storyboard

D. Evaluasi 1

Pada tahap evaluasi 1 dilakukan evaluasi dalam bentuk checklist. Hasil dari tahap evaluasi 1 didapatkan, dari 10 poin evaluasi sudah terlaksana seluruhnya

\section{E. Tahap 3}

1) Produksi

Pada Tahap 3 fase produksi dibagi menjadi 2, yaitu video production dan audio production. Pada tahap ini dilakukan pengambilan gambar (shooting) sesuai dengan storyline dan storyboard yang telah dibuat pada tahap 2. Proses shooting dilakukan di berbagai tempat tergantung dengan waktu yang dimiliki 
oleh narasumber serta kesiapan alat dan cuaca. Proses video production dapat dilihat pada Gambar 5.

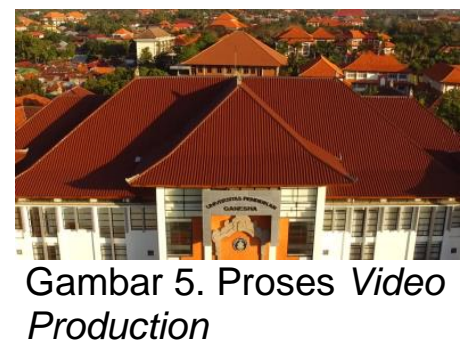

Audio production merupakan tahap produksi audio film dokumenter. Pada tahap ini dilakukan dengan cara merekam langsung dan meminta ijin penggunaan lagu kepada band maupun instasi yang memiliki hak cipta atas audio tersebut. Selain itu, dalam proses audio production ini juga dilakukan dengan cara menggunakan music - music yang tidak berbayar (free license), sehingga tidak menyalahi aturan hak cipta. Proses audio production dapat dilihat pada Gambar 6.

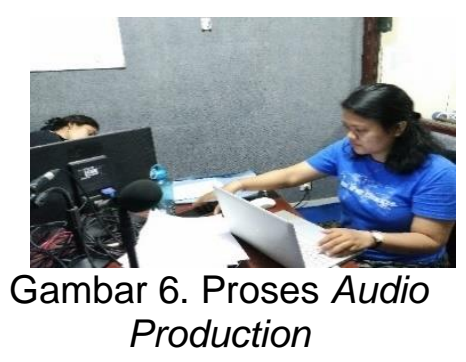

2) Pasca Produksi

[1] Video Editing

Untuk menunjang kegiatan video editing, maka digunakan dua aplikasi yang berfungsi untuk melakukan pengeditan video. Aplikasi - aplikasi tersebut antara lain :

a). Adobe Premiere Pro CS6

b). Adobe After Effect CS6

Pada tahap video editing menggunakan Adobe Premiere pro CS 6 ini menggunakan 6 track video, yaitu 3 track video dan gambar, 1 track nama narasumber dan nama lokasi, 1 track background dan 1 track untuk watermark. Pada tahap ini juga dilakukan penggabungan antara video dengan audio, dan color grading.
Proses video editing dapat dilihat pada gambar 7. Sedangkan proses pembuatan animasi dapat dilihat pada gambar 8.

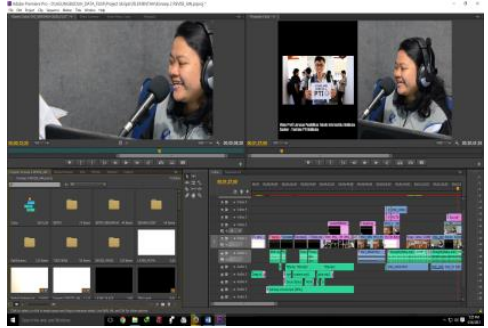

Gambar 7. Proses Video Editing

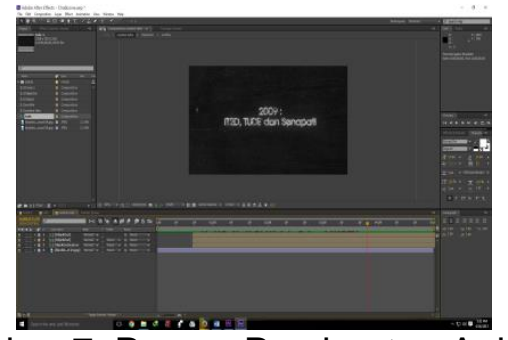

Gambar 7. Proses Pembuatan Animasi

[2] Sound Editing

Pada tahap sound editing, digunakan aplikasi yang bernama Adobe Audition CS6. Yang dilakukan dalam tahap ini adalah meminimalkan noise dan meningkatkan decibel suara. Kegiatan sound editing dapat dilihat pada gambar 8 .

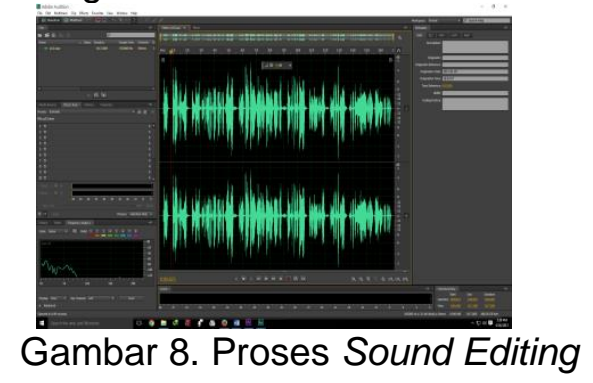

[3] Rendering

Rendering film PTI : Rumahku (Sebuah Catatan, Sebuah Kisah) menggunakan video codec H.264 resolusi $1280 \times 720$ dengan format MP4. Rendering film PTI : Rumahku (Sebuah Catatan, Sebuah Kisah) dapat dilihat pada gambar 9 . 


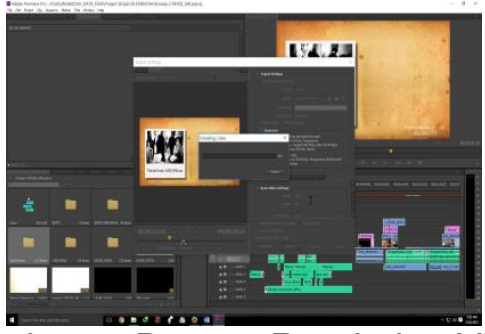

Gambar 9. Proses Rendering Video

[4] Review Editing

Setelah melewati proses rendering, maka dilakukan melihat kembali hasil pengeditan agar jika terdapat kesalahan dalam film, dapat dilakukan proses editing ulang sebelum nanti film siap diuji. Pada gambar 10 merupakan hasil rendering video

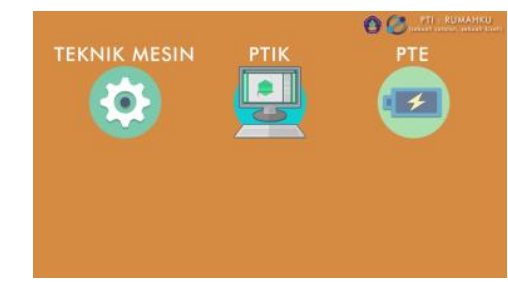

Gambar 10 Hasil Rendering Video

F. Evaluasi 2

1) Uji Ahli Isi

Uji ahli isi dilakukan oleh 2 orang dosen yang merintis berdirinya jurusan Pendidikan Teknik Informatika Undiksha Singaraja. Dari angket uji ahli isi yang disebar ke dua orang narasumber, kedua narasumber tersebut telah menyetujui atau telah mencentang seluruh poin dari angket uji ahli isi. Dengan kata lain seluruh dari film dokumenter PTI : Rumahku (Sebuah Catatan, Sebuah Kisah) sudah sesuai dengan sejarah PTI : Rumahku (Sebuah Catatan, Sebuah Kisah) tersebut

2) Uji Ahli Media

Dari angket uji ahli media yang disebar ke dua orang sinematografi, ke dua ahli tersebut telah menyetujui atau telah mencentang seluruh poin dari angket uji ahli media. Dengan kata lain seluruh dari film dokumenter PTI : Rumahku (Sebuah Catatan, Sebuah Kisah) sudah sesuai dengan kaidah-kaidah sinematografi. Oleh Karena itu, film dokumenter PTI :
Rumahku (Sebuah Catatan, Sebuah Kisah) sudah layak dipublikasikan dan diuji di lapangan

G. Tahap 4

Pada tahap ini dibagi menjadi 2 fase, yaitu Pada tahap ini dibagi menjadi 2 fase, yaitu desain cover DVD dan desain kepingan DVD. Hasil dari desain DVD dan cover DVD film dokunenter PTI : Rumahku (Sebuah Catatan, Sebuah Kisah) dapat dilihat pada Gambar 11 dan Gambar 12

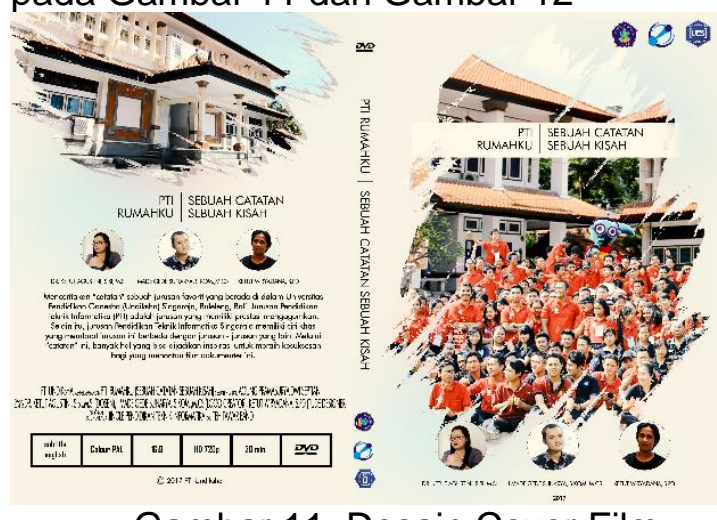

Gambar 11. Desain Cover Film

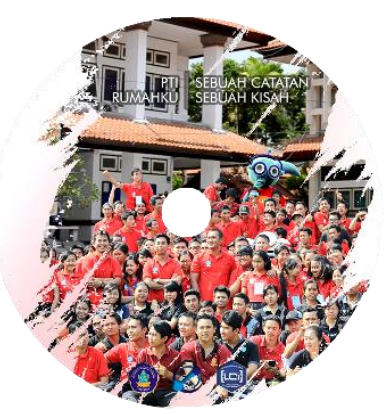

Gambar 12. Desain DVD Film

\section{H. Outcome}

Pada tahap ini dilakukan pembuatan poster serta trailer yang digunakan sebagai sarana promosi publikasi yang nantinya akan bekerjasama dengan jurusan Pendidikan Teknik Informatika. Adapun desain poster dari film dokumenter Film Dokumenter PTI : Rumahku (Sebuah Catatan, Sebuah Kisah) dapat dilihat pada Gambar 13. 


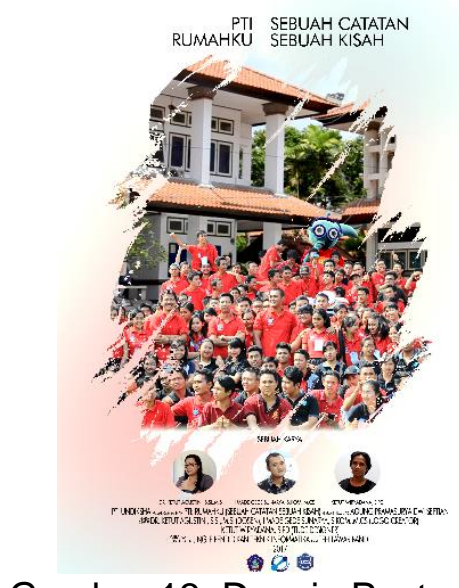

Gambar 13. Desain Poster Film

Selain poster dan trailer pada tahap ini juga dilakukan uji respon penonton. Hasil respon penonton Film Dokumenter PTI : Rumahku (Sebuah Catatan, Sebuah Kisah) dilakukan untuk mengetahui tanggapan atau respon penonton setelah menonton film dokumenter ini. Uji respon penonton dilakukan dengan cara menyebarkan angket kepada 40 orang responden dari kalangan mahasiswa jurusan Pendidikan Teknik Informatika. Berdasarkan data uji responden yang telah dilakukan, didapatkan hasil rata-rata presentase yaitu $91,6 \%$ dengan tingkat pencapaian sangat baik dengan hasil tersebut maka dapat dikatakan bahwa film dokumenter PTI : Rumahku (Sebuah Catatan, Sebuah Kisah) respon yang sangat baik dari penonton

\section{PEMBAHASAN}

PTI : Rumahku (Sebuah Catatan, Sebuah Kisah) bertujuan untuk memperkenalkan, memberikan informasi tentang jurusan Pendidikan Teknik Informatika Undiksha Singaraja sekaligus sebagai media untuk menginspirasi civitas akademika jurusan Pendidikan Teknik Informatika Undiksha Singaraja agar bisa lebih berprestasi lagi.

Dalam pengembangan film dokumenter ini menggunakan model cyclic strategy. Pada tahap brief pembuatan film dokumenter ini dilakukan pengajuan ide atau topik kepada ketua jurusan Pendidikan Teknik Informatika. Setelah ide atau topik telah disetujui selanjutnya menuju ke tahap 1 yaitu melakukan pengumpulan data dan analisis kebutuhan film. Pada proses pengumpulan data didapatkan data dan informasi mengenai sejarah berdirinya jurusan Pendidikan Teknik Informatika Undiksha Singaraja dan juga informasi mengenai latar belakang terciptanya logo jurusan, karakter Tude dan jingle PTI. Selain itu, juga didapatkan data bahwa berdasarkan hasil penyebaran angket yang disebarkan ke mahasiswa jurusan Pendidikan Teknik Informatika Undiksha Singaraja. didapatkan kesimpulan bahwa $90 \%$ dari responden tidak mengetahui sejarah jurusan Pendidikan Teknik Informatika Undiksha Singaraja. Kemudian setelah proses pengumpulan data selesai, maka dilakukan proses analisis kebutuhan film. Analisis kebutuhan film dokumenter PTI : Rumahku (Sebuah Catatan, Sebuah Kisah) yaitu analisa talent, analisa lokasi, analisa peralatan, analisa crew, analisa SWOT dan analisa STP.

Tahap 2 adalah proses pra produksi film dokumenter PTI : Rumahku (Sebuah Catatan, Sebuah Kisah) dimana pada tahapan ini dilakukan pembuatan ide cerita yang didapatkan berdasarkan wawancara dengan para narasumber film dokumenter PTI : Rumahku (Sebuah Catatan, Sebuah Kisah). Kemudian pembuatan sinopsis film dokumenter PTI : Rumahku (Sebuah Catatan, Sebuah Kisah) yang dibuat berdasarkan ide cerita yang telah didapatkan. Selanjutnya adalah pembuatan storyline, skenario dan storyboard yang dibuat untuk mempermudah proses pembuatan film dokumenter PTI : Rumahku (Sebuah Catatan, Sebuah Kisah). Setelah itu dilakukan Evaluasi Tahap 1 yaitu menguji kelengkapan pada Tahap 1 dan Tahap 2. 
Tahap 3 merupakan tahapan produksi film dokumenter PTI : Rumahku (Sebuah Catatan, Sebuah Kisah) dimana pada tahapan ini dilakukan proses produksi film (video production dan audio production). Setelah proses produksi film selesai dilakukan, maka selanjutnya dilakukan tahapan pasca produksi film dokumenter dimana tahapan ini adalah proses editing video film dokumenter, pembuatan animasi dan efek film, mixing, dan rendering. Setelah selesai Tahap 3, maka dilakukan evaluasi kedua yaitu uji ahli isi dan uji ahli media. Hasil pengujian uji ahli isi terhadap film dokumenter PTI : Rumahku (Sebuah Catatan, Sebuah Kisah) dengan menggunakan angket menunjukan bahwa isi informasi didalam film dokumenter PTI : Rumahku (Sebuah Catatan, Sebuah Kisah) adalah sesuai dan layak untuk dilanjutkan. Saran tambahan dari Bapak I Made Gede Sunarya, S.Kom.,M.Cs (penguji ahli isi 2) mengatakan bahwa sebaiknya pada awal film/intro, sebaiknya ditambahkan logo dari Laboratory of Cultural Informatics. Hasil uji media film dokumenter PTI : Rumahku (Sebuah Catatan, Sebuah Kisah) berdasarkan pengujian yang dilakukan oleh dua orang sudah dinyatakan sesuai. Saran dari Bapak Putu Novayana, S.Kom (penguji ahli media 1) mengatakan bahwa film dokumenter PTI : Rumahku (Sebuah Catatan, Sebuah Kisah) sudah sangat bagus dan sangat cocok dijadikan salah satu media promosi untuk jurusan dokumenter PTI : Rumahku (Sebuah Catatan, Sebuah Kisah). Sedangkan saran dari Bapak I Gusti Ngurah Agung Sukrisna, S.Sn (penguji ahli media 2) mengatakan bahwa secara konsep cerita sudah bagus dan menarik. Tapi lebih ditekankan kepada penonton harus lebih serius menyaksikan karena alur cerita menggunakan alur mundur (flashback). Jadi dapat dinyatakan film dokumenter PTI : Rumahku (Sebuah Catatan, Sebuah Kisah) sudah layak untuk dilanjutkan untuk pengujian respon penonton.

Tahap 4 dilakukan proses mastering file yang sudah dirender dikemas dalam bentuk DVD dan dapat dipublikasikan. Tahap outcome merupakan tahap terakhir pembuatan film dokumenter PTI : Rumahku (Sebuah Catatan, Sebuah Kisah). Tahapan outcome adalah tahapan terakhir. Pada tahapan ini film dokumenter PTI : Rumahku (Sebuah Catatan, Sebuah Kisah) sudah siap dipublikasikan. Pada tahap ini juga dilakukan uji respon penonton.

Uji respon penonton adalah pengujian untuk mengetahui bagaimana respon dari penonton setelah menonton film dokumenter PTI : Rumahku (Sebuah Catatan, Sebuah Kisah). Pada tahap uji respon penonton terdapat kesulitan yaitu sulitnya mencari jenis angket yang cocok terhadap film dokumenter. Jenis angket uji respon penonton yang paling cocok adalah menggunakan jenis angket user experience, namun peneliti mendapat kendala dalam menentukan butir pernyataan dari angket uji respon tersebut dan juga karena keterbatasan waktu penelitian. Maka peneliti menggunakan jenis angket skala likert. Uji respon penonton dilakukan terhadap 40 orang responden yang merupakan mahasiswa. Hasil uji respon penonton didapatkan bahwa presentase yang diperoleh adalah $91,6 \%$ yang dikonversikan kedalam tabel konversi menyatakan sangat baik.

Berdasarkan hasil analisis uji respon penonton film dokumenter PTI : Rumahku (Sebuah Catatan, Sebuah Kisah), didapatkan fakta bahwa butir - butir soal yang mendapatkan nilai tertinggi adalah pada butir soal nomor 15 yaitu Dengan menonton film dokumenter PTI : Rumahku (Sebuah Catatan, Sebuah Kisah), saya ingin berprestasi serta menghasilkan karya - karya yang lebih baik lagi. Selain itu, pada butir soal nomor 1 yaitu Dengan menonton film dokumenter 
PTI : Rumahku (Sebuah Catatan, Sebuah Kisah) saya mengetahui sejarah berdirinya jurusan Pendidikan Teknik Informatika Undiksha dan butir soal nomor 4 yaitu Setelah menonton film dokumenter PTI : Rumahku (Sebuah Catatan, Sebuah Kisah), saya mengetahui siapa saja yang berkontribusi dalam pembuatan logo jurusan, karakter Tude dan jingle PTI juga mendapat nilai yang tinggi. Hasil analisis uji respon penonton ini menunjukan bahwa setelah menonton film documenter PTI : Rumahku (Sebuah Catatan, Sebuah Kisah), penonton bisa mengetahui sejarah berdirinya jurusan Pendidikan Teknik Informatika Undiksha dan orang orang yang berkontribusi dalam pembuatan logo jurusan, karakter Tude dan jingle PTI sehingga penonton terinspirasi untuk berprestasi dan menghasilkan karya karya yang lebih baik lagi. Ini sesuai dengan teori dari Kamus Besar Bahasa Indonesia bahwa dokumenter adalah dokumentasi dalam bentuk film mengenai suatu peristiwa bersejarah atau suatu aspek seni budaya yang mempunyai makna khusus agar dapat menjadi alat penerangan dan alat pendidikan. Hasil uji respon penonton film dokumenter PTI : Rumahku (Sebuah Catatan, Sebuah Kisah) dikategorikan sangat baik karena peneliti mengangkat permasalahan tentang ketidaktahuan mahasiswa terhadap jurusan. Hal ini sesuai dengan pendapat dari Prihantono, Natadja, \& Setiawan (2009) yaitu strategi yang efektif untuk membuat film dokumenter yang menarik dan tepat sasaran adalah mencari masalahmasalah aktual yang sedang hangat di masyarakat, sehingga audience penasaran untuk menemukan jawabannya dalam film dokumenter tersebut.

Penelitian film dokumenter PTI : Rumahku (Sebuah Catatan, Sebuah Kisah) dalam proses penelitiaannya mengalami beberapa kendala. Kendala yang dialami diantaranya terbatasnya peralatan untuk pengambilan gambar, kesibukan masing - masing crew karena sebagian besar juga sedang melakukan penelitian. Kendala lain yang dialami dalam proses pembuatan film ini adalah kesibukan narasumber dan kurangnya dokumentasi - dokumentasi kegiatan pada saat baru berdiri. Kesibukan narasumber dapat dimaklumi karena narasumber berprofesi sebagai dosen dan fotografer sehingga terkadang narasumber sering membatalkan janji pengambilan gambar. Selain itu, banyak alumni jurusan Pendidikan Teknik Informatika Undiksha Singaraja yang berprestasi sulit dihubungi untuk melakukan wawancara yang menyebabkan perubahan konsep awal dari cerita film dokumenter ini.

Berdasarkan pembahasan diatas, penilaian-penilaian yang sudah dilakukan oleh uji ahli isi, uji ahli media dan uji responden dapat dikategorikan sangat baik dan mendapatkan respon positif. Dari penilaian tersebut, secara garis besar film dokumenter PTI : Rumahku (Sebuah Catatan, Sebuah Kisah) layak untuk di publikasikan ke masyarakat luas.

\section{SIMPULAN DAN SARAN}

Berdasarkan hasil penelitian dan pembahasan pada penelitian film dokumenter PTI : Rumahku (Sebuah Catatan, Sebuah Kisah), maka penulis dapat menarik kesimpulan sebagai berikut.

1. Perancangan film dokumenter PTI : Rumahku (Sebuah Catatan, Sebuah Kisah) telah berhasil dilaksanakan menggunakan model cyclic strategy dengan menggunakan tahapan produksi film yaitu pra produksi (pre production), proses produksi (production), pasca produksi (post production) dan pengujian. 
2. Film dokumenter PTI : Rumahku (Sebuah Catatan, Sebuah Kisah) sudah berhasil masuk dalam kategori sangat baik sesuai dengan hasil uji ahli isi dan uji ahli media dimana semua penguji menyatakan setiap butir pernyataan sudah sesuai.

3. Berdasarkan analisis terhadap 40 orang responden yang berasal dari kalangan mahasiswa dinyatakan bahwa film dokumenter PTI : Rumahku (Sebuah Catatan, Sebuah Kisah) mendapatkan total hasil persentase sebesar $91,6 \%$ yang masuk dalam kategori sangat baik.

Beberapa hal yang dapat disampaikan sebagai bahan pertimbangan lebih lanjut adalah pegujian respon penonton untuk penelitian film dokumenter akan lebih baik jika menggunakan uji user experience agar pembuat film bisa mengetahui kelemahan dari film dokumenternya. Bagi peneliti selanjutnya diharapkan agar bisa membuat film dokumenter kreatif yang didalam film dokumenternya terdapat unsur konflik

\section{DAFTAR PUSTAKA}

Ana, C. (2015, March 7). Kategori : Pendidikan : 18 Manfaat Belajar Sejarah Bagi Kehidupan. Retrieved May 20, 2016, from 18 Manfaat Belajar Sejarah Bagi Kehidupan: www.manfaat.co.id

Karisma, I. E., \& Masnuna. (2013). Film Dokumenter Urban Sport "Bike Trial". Jurnal Desain Komunikasi Visual UPN "Veteran" Jatim Volume 2, 20-25.

Cheng, K. G., \& Barker, T. (2011). Mau Dibawa ke Mana Sinema Kita? Beberapa Wacana Seputar Film Indonesia. Jakarta: Salemba Humanika.

Taufik, A., Prayanto, \& Yudani, H. D. (2013). Perancangan Film
Dokumenter Perjalanan Hidup R.A Kartini. 1-14.

Effendy, H. (2011). Industri Perfilman Indonesia, Sebuah Kajian. Jakarta: Erlangga

Kebudayaan, K. P. (2016, January 3). Badan Pengembangan dan Pembinaan Bahasa. Retrieved from KBBI Daring: https://kbbi.kemdikbud.go.id/

Prihantono, O., Natadja, L., \& Setiawan, D. (2009). Strategi Pembuatan Film Dokumenter yang Tepat untuk Mengangkat Tradisi-Tradisi di Balik Reog Ponorogo. Jurnal Desain Komunikasi Visual Nirmana, Vol. 11, No. 1, 1-10.

School, I. D. (2014, Agustus 16). Jenis-jenis Film Dokumenter IDS _ International Design School Jakarta. Retrieved Desember 25, 2015, from IDS Website: http://www.IDS.com

Suardika, I. M. (2017). Film Dokumenter Genggong (Sebuah Musik Kuno). JANAPATI, 60-69.

Sarwono, Jonathan, and Hary Lubis. 2007. Metode Riset untuk Desain Komunikasi Visual. Yogyakarta: Andi.

Grohl, D. (Director). (2013). Sound City [Motion Picture]. 